\title{
OCENA WARTOŚCI OZDOBNEJ WYBRANYCH GATUNKÓW KLONÓW ACER L. NA PODSTAWIE OBSERWACJI FENOLOGICZNYCH
}

\section{EVALUATION OF DECORATIVE VALUE OF SELECTED SPECIES OF MAPLES ACER L. BASED ON PHENOLOGICAL OBSERVATIONS}

\author{
Mateusz Sowelo, Wojciech AntKowiak
}

\begin{abstract}
W. Antkowiak, Katedra Botaniki, Uniwersytet Przyrodniczy w Poznaniu, ul. Wojska Polskiego 71 C, 60-625 Poznań, Poland, e-mail: wojciech.antkowiak@up.poznan.pl

M. Sowelo, Ogród Botaniczny Uniwersytetu im. Adama Mickiewicza w Poznaniu, ul. Dąbrowskiego 165, 60-594 Poznań, Poland, e-mail: matsow@amu.edu.pl
\end{abstract}

(September 20, 2018. Accepted: October 12, 2018)

\begin{abstract}
Aвstract. The paper presents the results of phenological observations carried out in 2017 on the following species of maples: Acer buergerianum, A. campestre, A. capillipes, A. cappadocicum, A. carpinifolium, A. circinatum, A. cissifolium, A. davidii, A. diabolicum, A. griseum, A. japonicum, A. maximowiczianum, A. miyabei, A. mono, A. palmatum, A. platanoides, A. rubrum, A. rufinerve, A. saccharum, A. shirasawanum, A. stachyophyllum, A. tataricum, A. tataricum ssp. ginnala and $A$. truncatum. The studies have been conducted in the Botanical Garden of Adam Mickiewicz University in Poznań based on the SHENNiKov research method (1928) modified by ŁUKASIEWICZ (1984). Observations have shown that the longest foliage period have species: A. japonicum, A. mono, A. platanoides and A. rubrum, while the longest duration of the autumn leaf discoloration is characterized by $A$. stachyophyllum, A. circinatum, A. palmatum, A. mono and female specimen of A. cissifolium. In addition all studied species, except $A$. buergerianum, A. capillipes, A. circinatum, A. tataricum and A. tataricum ssp. ginnala, are distinguished by the attractive autumn color of the leaves. The longest flowering period was in A. truncatum, A. stachyophyllum, A. circinatum and A. palmatum, while A. buergerianum, A. diabolicum and $A$. saccharum did not bloom at all. The most attractive flowers have $A$. davidii and $A$. platanoides and the most decorative fruits have $A$. capillipes, $A$. davidii, A. tataricum and $A$. tataricum ssp. ginnala. Studies have also shown that $A$. mono, A. rubrum and $A$. rufinerve did not fruition at all. The species of maple with the highest number of positive traits is Acer davidii, therefore it should be used as often as possible in green areas.
\end{abstract}

KEY WORDS: seasonal rhythm, climate factors, Acer

\section{WSTĘP}

Fenologia zajmuje się zjawiskami występującymi okresowo w przyrodzie, zależnymi od pór roku i zmian pogody (KRotoska 1958, Harmata 1995). Dzięki prowadzonym obserwacjom i notowaniu dat pojawów fenologicznych, możliwe jest precyzyjne zmierzenie czasu trwania walorów zdobniczych. Prowadzenie długoletnich badań umożliwia wyodrębnienie nie tylko gatunków cechujących się największą odpornością na niekorzystne warunki środowiskowe, lecz także stałością fenologiczną. Świadczy o niej na przykład kwitnienie danego gatunku zawsze o tej samej fenologicznej porze roku. Pozyskane w ten sposób informacje mogą okazać się cenne zarówno dla projektantów terenów zieleni, jak i amatorów ogrodnictwa.

W kolekcji Ogrodu Botanicznego Uniwersytetu im. Adama Mickiewicza znajdują się 42 gatunki klonów. Są to nierzadko okazy kilkudziesięcioletnie, które przetrwały skrajne warunki atmosferyczne lat i zim. Mimo to wiele $z$ nich nie jest rozpowszechnionych i nie figuruje w zestawieniach roślin polecanych do stosowania na terenach zieleni (ŁUKASIEWICz 1995, LENARD i WolsKi 2006, FILIPCZAK 2011). O wartości danych gatunków, poza odpornością na niekorzystne 
warunki środowiskowe, świadczą również walory zdobnicze. Można do nich zaliczyć m.in. długość kwitnienia i listnienia wraz z jesiennym przebarwieniem liści. Szczegółowych danych na ten temat dostarczają badania fenologiczne (BIELAWsKA i in. 1964, ВіАєОВОК 1971).

Celem niniejszej pracy było przeprowadzenie badań fenologicznych na 24 gatunkach klonów, aby na podstawie uzyskanych wyników wytypować gatunki odznaczające się największą wartością zdobniczą.

\section{TEREN BADAŃ, MATERIAŁ I METODY}

Obserwacje fenologiczne przeprowadzono w Ogrodzie Botanicznym Uniwersytetu im. Adama Mickiewicza w Poznaniu od marca do grudnia 2017 roku. Badaniami objęto 24 gatunki klonów należące do 12 sekcji: Palmata: Acer circinatum Pursh - klon okrągłolistny (nr ewidencyjny 0938), A. japonicum Thunb. k. japoński (3132), A. palmatum Thunb. - k. palmowy (2412), A. shirasawanum Koidz. - k. Shirasawy (0831), Macrantha: A. capillipes Maxim. - k. cienkoszyputkowy (0735), A. davidii Franch. - k. Davida (1742), A. rufinerve Siebold \& Zucc. - k. rdzawy (1747), Glabra: A. stachyophyllum Hiern - k. stachiurkolistny (3422), Negundo: A. cissifolium (Siebold \& Zucc.) K. Koch - k. winolistny (0722), Indivisa: A. carpinifolium Siebold \& Zucc. - k. grabolistny (2346), Acer: A. saccharum Marshall - k. cukrowy (3411), Pentaphylla: A. buergerianum Miq. - k. Bürgera (0552),
Trifoliata: A. griseum Pax - k. strzępiastokory (3420, 7417), A. maximowiczianum Miq. - k. Maksimowicza (0818), Lithocarpa: A. diabolicum Blume ex K. Koch - k. kosmaty (0823), Platanoidea: A. campestre L. k. polny (3797), A. cappadocicum Gled. - k. kolchidzki - (1252), A. miyabei Maxim. - k. Miyabego (0825), A. mono Maxim. - k. mono (4530), A. platanoides L. k. pospolity (6906), A. truncatum Bunge - k. ściętolistny (2456), Ginnala: A. tataricum L. - k. tatarski (3940), A tataricum ssp. ginnala (Maxim.) Wesm. k. Ginnala (6391), Rubra: A. rubrum L. - k. czerwony (1778).

Polskie nazwy gatunkowe przyjęto za BugazA (2000), przynależność do sekcji za GeLDERenem i in. (1995), rozmieszczenie badanych klonów w Ogrodzie Botanicznym przedstawiono na rycinie 1.

Każdy gatunek objęty badaniami był reprezentowany przez jeden okaz, z wyjątkiem klonu strzępiastokorego A. griseum i winolistnego A. cissifolium, w przypadku których obserwowano dwie rośliny. Klon strzępiastokory o numerze ewidencyjnym 3420, rosnący w cieniu, oznaczono symbolem - a drzewo o numerze 7417 , rosnące na stanowisku słonecznym, oznaczono znaczkiem -ợ:. W przypadku klonu wino-

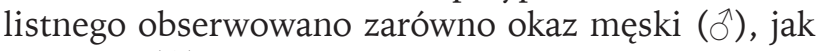
i żeński (†), o wspólnym numerze ewidencyjnym 0722.

Metody badawcze przyjęto za ŁUKASIEWICZEM (1984). Notowania dat pojawów fenologicznych prowadzono w przypadku kwiatów cztery razy

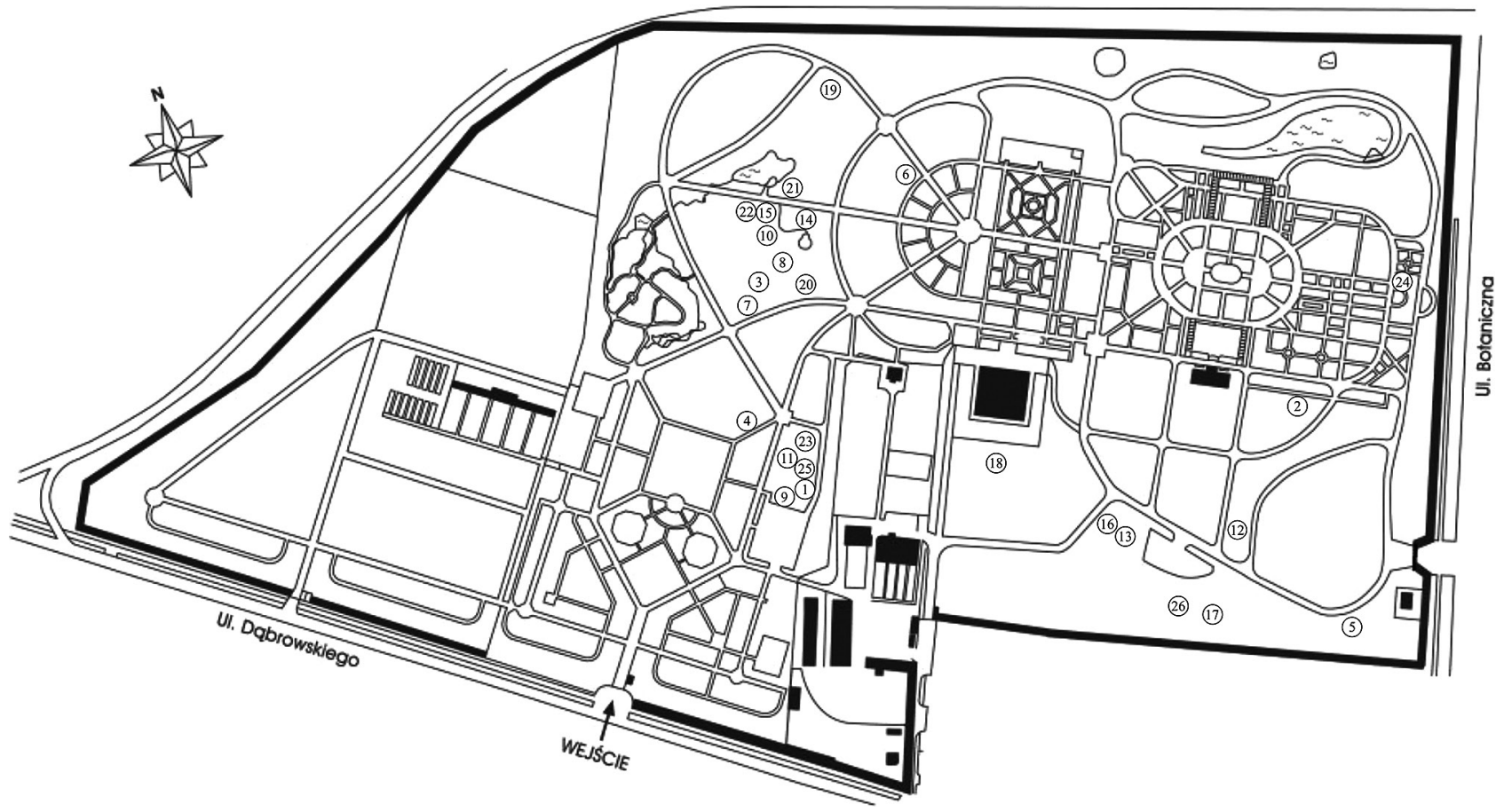

Ryc. 1. Plan Ogrodu Botanicznego UAM (https://omp.oop.org.pl/ogrody/ogrod-botaniczny-w-poznaniu/) z naniesionymi stanowiskami badanych klonów. Numery drzew zgodne z numeracją gatunków w tabeli 4

Fig. 1. The plan of the Botanical Garden of the Adam Mickiewicz University in Poznań (https://omp.oop.org.pl/ogrody/ ogrod-botaniczny-w-poznaniu/) with the distribution of analysed maple species. The numbers of trees according to the numbering of species in the Table 4 


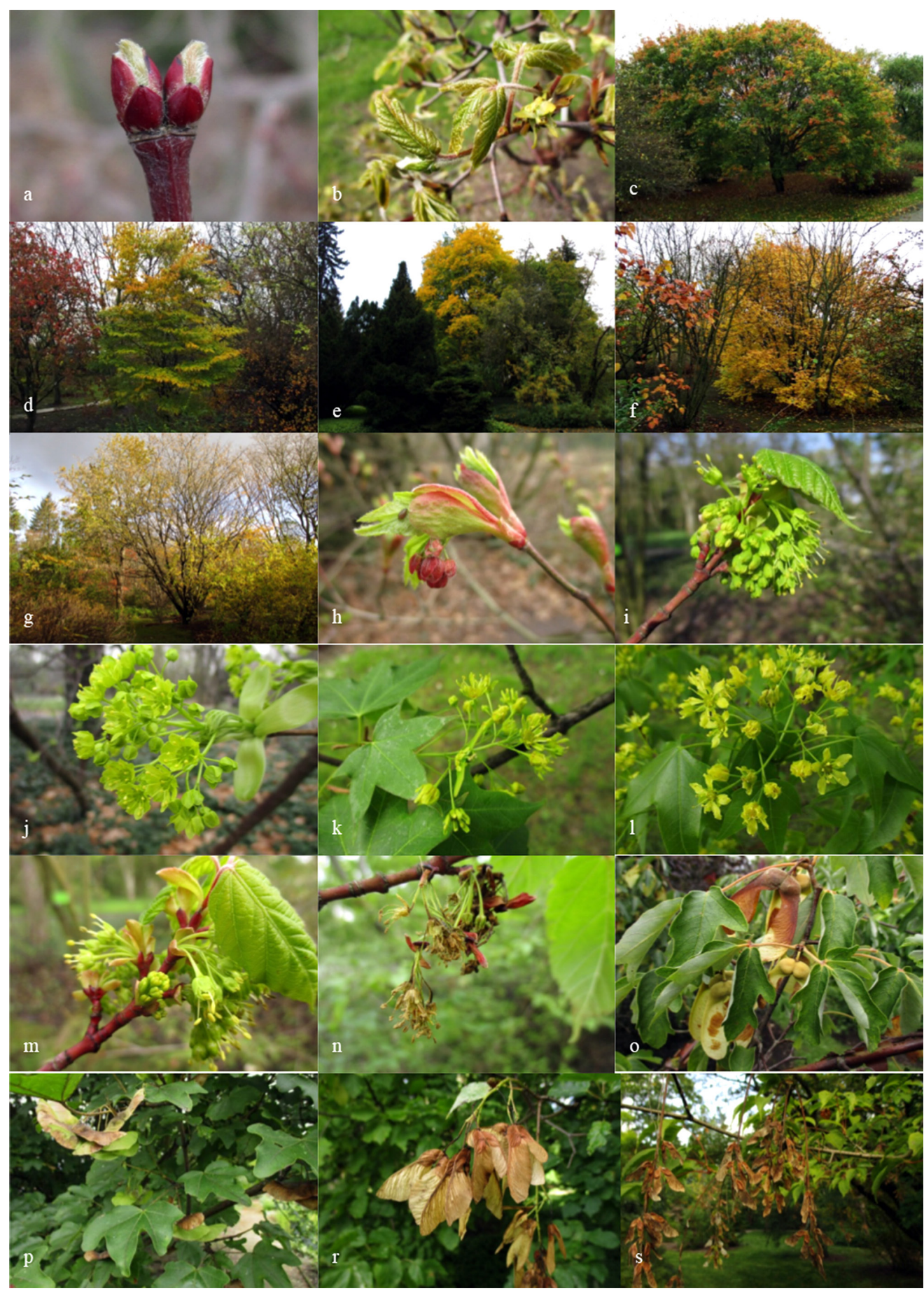

Ryc. 2. Fazy rozwojowe klonów. Początek: otwierania się pąków liściowych A. circinatum (a), rozchylania się blaszek liściowych A. griseum (b), jesiennego przebarwiania się liści A. mono (c), pełni jesiennego przebarwiania A. carpinifolium (d), koniec pełni jesiennego przebarwiania A. cappadocicum (e), początek opadania liści A. japonicum (f), koniec opadania liści $A$. cissifolium (g), pojawienie się pierwszych pąków kwiatostanowych $A$. japonicum (h), pojawienie się pierwszych kwiatów A. stachyophyllum (i), początek pełni kwitnienia A. platanoides (j), pierwsze kwiaty przekwitłe A. truncatum (k), koniec pełni kwitnienia A. mono (l), ostatnie pąki kwiatowe A. capillipes (m), koniec kwitnienia A. stachyophyllum (n), początek dojrzewania owoców A. griseum (o), początek pełni dojrzewania owoców A. campestre (p), koniec dojrzewania owoców A. tataricum (r), początek rozsiewania się owoców A. cissifolium (s)

Fig. 2. The developmental phase of maples. Onset of leaf bud break A. circinatum (a), onset of leaf blade opening A. griseum (b), onset of autumn leaf colour change $A$. mono (c), onset of full autumn leaf colour change A. carpinifolium (d), end of full autumn leaf colour change A. cappadocicum (e), onset of leaf fall A. japonicum (f), end of leaf fall A. cissifolium (g), appearance of the first inflorescence buds A. japonicum (h), blooming of the first flowers A. stachyophyllum (i), onset of anthesis A. platanoides (j), first flowers out of bloom A. truncatum (k), end of full anthesis A. mono (l), last flower buds A. capillipes (m), end of flowering A. stachyophyllum (n), onset of fruit ripening A. griseum (o), onset of full fruit ripening A. campestre (p), end of fruit ripening A. tataricum (r), onset of fruit dispersal A. cissifolium (s) 
w tygodniu, a obserwacje fazy rozwoju wegetatywnego i owoców z częstotliwością nie mniejszą niż dwa razy w tygodniu. W celu zobrazowania wyników sporządzono spektra fenologiczne zmodyfikowaną przez ŁUKASIEWICZA (1984) metodą SZENNIKOva (1928). Obserwowano następujące fazy rozwoju liści:

\section{FAZY ROZWOJU WEGETATYWNEGO}

1. początek otwierania się pąków liściowych (rozchylanie lub rozsuwanie lusek okrywających; widoczne stają się: jaśniej zabarwiony wierzchołek rozwijającego się pąka lub jaśniej zabarwione części nasad łusek wskutek ich rozsuwania się; ryc. $2 a)$,

2. początek rozchylania się blaszek liściowych (pierwsze liście rozprostowują blaszkę, ukazując jej wierzchnią stronę; ryc. 2b),

Tabela 1. Dane klimatyczne dla roku obserwacji i dziesięciolecia poprzedzającego badania

Table 1. Weather data for the year of observations and the decade preceding the study

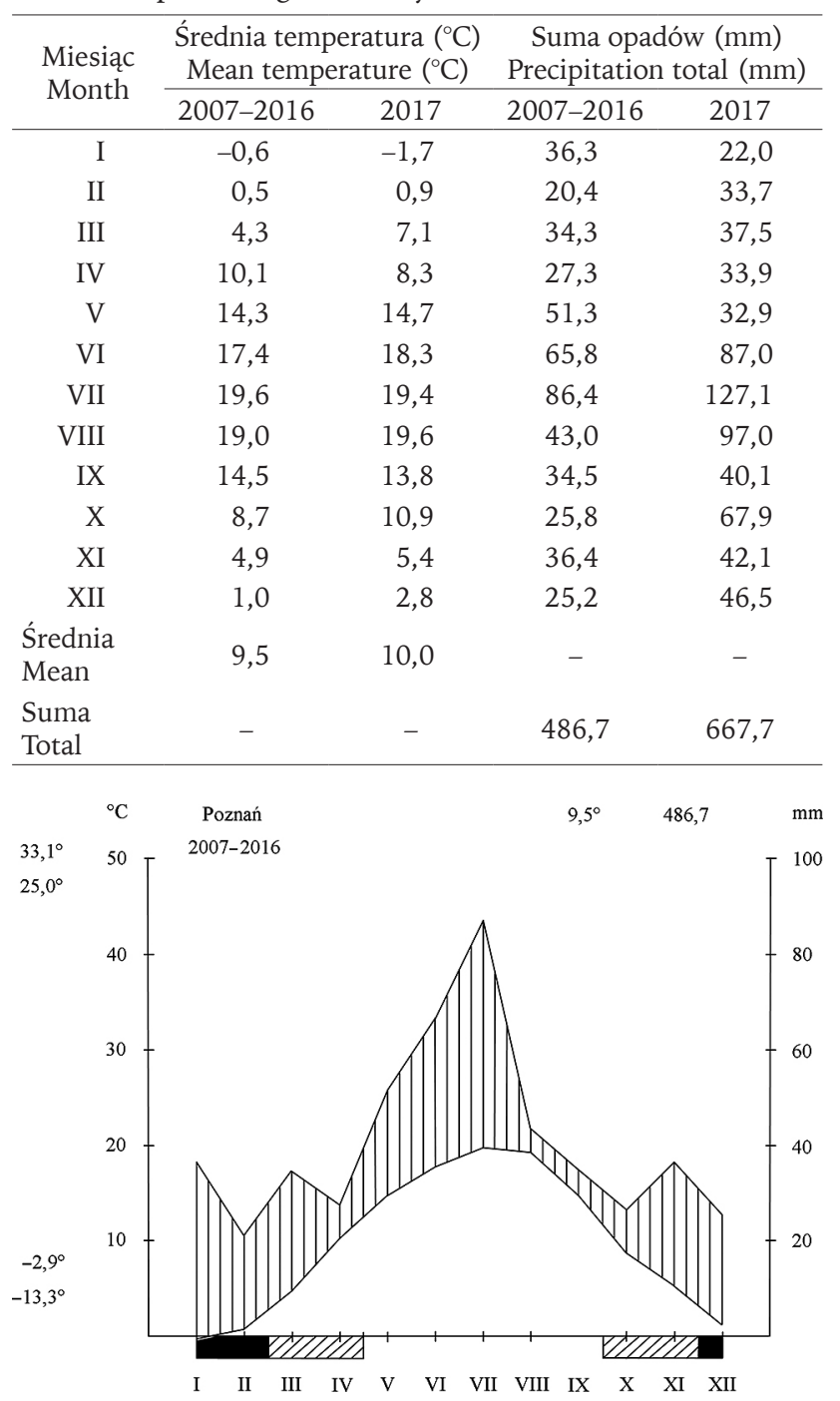

3. początek jesiennego przebarwiania się liści (wyraźna zmiany barwy u około $10 \%$ liści; ryc. 2c),

4. początek pełni jesiennego przebarwiania (około $50 \%$ liści przebarwionych; ryc. $2 \mathrm{~d}$ ),

5. koniec pełni jesiennego przebarwiania (około $90 \%$ liści przebarwionych; ryc. 2e),

6. utrata dekoracyjnego zabarwienia liści jesienią,

7. początek opadania liści (ryc. 2 f),

8. koniec opadania liści (wszystkie liście opadły, względnie pozostały tylko pojedyncze; ryc. $2 \mathrm{~g}$ ).

Tabela 2. Średnie skrajne oraz średnie temperatury minimalne i maksymalne w latach 2007-2016 i w 2017 roku $\left({ }^{\circ} \mathrm{C}\right)$

Table 2. Extreme and mean minimum and maximum temperatures in 2007-2016 and $2017\left({ }^{\circ} \mathrm{C}\right)$

\begin{tabular}{|c|c|c|c|c|c|c|c|c|}
\hline & \multicolumn{4}{|c|}{ 2007-2016 } & \multicolumn{4}{|c|}{2017} \\
\hline . & 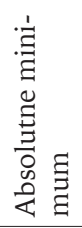 & 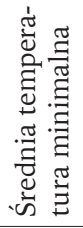 & 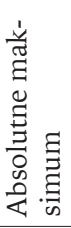 & 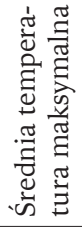 & 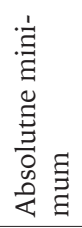 & 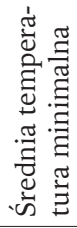 & 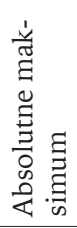 & 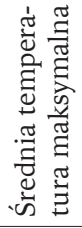 \\
\hline 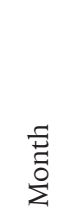 & 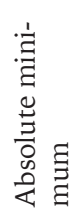 & 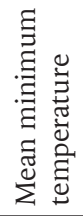 & 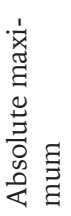 & 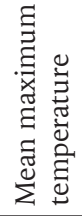 & 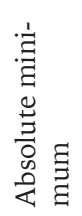 & 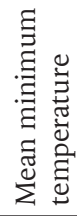 & 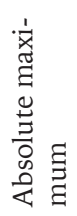 & 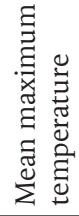 \\
\hline I & $-13,3$ & $-2,9$ & 8,9 & 1,5 & $-12,1$ & $-4,5$ & 4,6 & 0,8 \\
\hline II & $-10,0$ & $-2,2$ & 10,7 & 3,3 & $-7,5$ & $-1,6$ & 13, & 3,8 \\
\hline III & $-6,6$ & 0,2 & 16,4 & 8,3 & $-1,2$ & 2,9 & 23,0 & 12,1 \\
\hline IV & $-1,7$ & 4,7 & 25,0 & 15,3 & $-2,0$ & 4,2 & 25,0 & 13,4 \\
\hline V & & 8,6 & 27,9 & 19,5 & 0,2 & 11,3 & 29,6 & 17,8 \\
\hline VI & 6,6 & 1,9 & 31,5 & 22,6 & 10,1 & 20,0 & 29,4 & 16,0 \\
\hline VII & 9,6 & 14,5 & 33,1 & 25 , & 8,5 & 14,1 & 33,4 & 25,3 \\
\hline VIII & 7,3 & 13,7 & 32,3 & 24,4 & 9,0 & 14,0 & 35,2 & 25,8 \\
\hline IX & 3 , & 9,8 & 27,9 & 19,7 & 5,6 & 9,9 & 24,1 & 18,5 \\
\hline $\mathrm{X}$ & $-2,0$ & 5,2 & 20,8 & 12,9 & & 7,5 & 22,4 & 15,0 \\
\hline XI & $-3,9$ & 2,4 & 15,4 & 7,8 & $-2,9$ & 3,1 & 14,1 & 7,4 \\
\hline XII & $-8,9$ & $-1,4$ & 9,6 & 3,2 & $-3,2$ & 0,4 & 10,0 & 4,8 \\
\hline
\end{tabular}

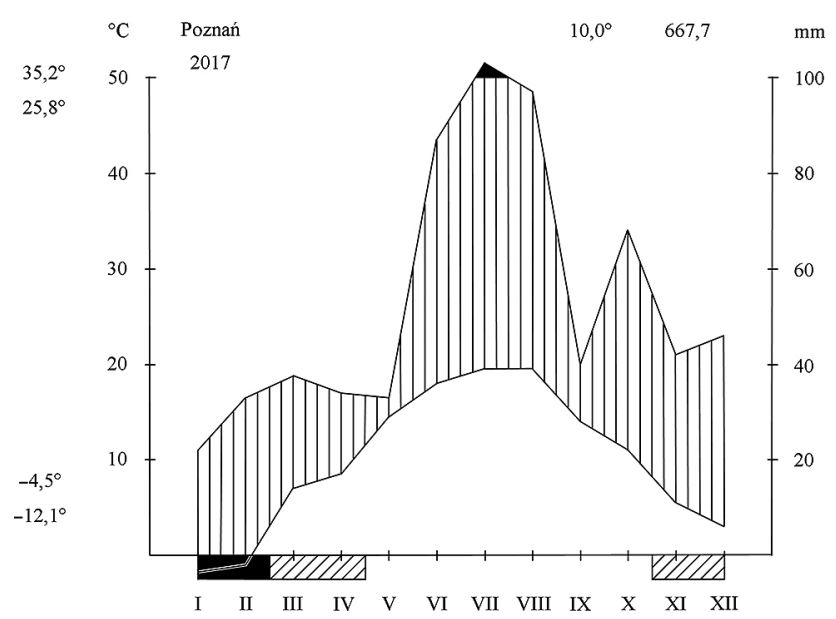

Ryc. 3. Diagram pluwiotermiczny Gaussena-Waltera dla lat 2007-2016 (a) oraz 2017 roku (b)

Fig. 3. The ombrothermic diagram according to Gaussen-Walter for the period of 2007-2016 (a) and for 2017 (b) 


\section{FAZY ROZWOJU KWIATÓW}

9. pojawienie się pierwszych pąków kwiatowych lub kwiatostanowych (ryc. 2h),

10. zakwitanie pierwszych kwiatów (kilka pierwszych kwiatów całkowicie otwartych; ryc. 2i),

11. początek pełni kwitnienia (około $25 \%$ całkowicie otwartych kwiatów; początek efektu masowego kwitnienia; ryc. 2j),

12. pierwsze kwiaty przekwitłe (początek pierwszych niedojrzałych owoców; ryc. 2k),

13. koniec pełni kwitnienia (około $75 \%$ kwiatów przekwitlych; koniec efektu masowego kwitnienia; ryc. 21),

14. ostatnie pąki kwiatowe (ryc. $2 \mathrm{~m}$ ),

15. koniec kwitnienia (data przekwitnięcia ostatnich kwiatów; ryc. 2n).

\section{FAZY ROZWOJU OWOCÓW}

16. początek dojrzewania owoców (pierwsze owoce zmieniają barwę i konsystencję; ryc. 2o),
17. początek pełni dojrzewania owoców (około 50\% owoców przybiera właściwe dla tej fazy zabarwienie i konsystencję; ryc. 2p),

18. koniec dojrzewania owoców (wszystkie owoce dojrzały; ryc. 2r),

19. początek rozsiewania się owoców (zaczynają opadać pierwsze owoce; ryc. $2 \mathrm{~s}$ ),

20. pełnia rozsiewania (około połowa owoców została rozsiana),

21. koniec rozsiewania (opadnięcie wszystkich lub prawie wszystkich owoców).

\section{WARUNKI KLIMATYCZNE}

Dane meteorologiczne pozyskano ze Stacji Doświadczalnej Marcelin (ul. Zgorzelecka 4) Uniwersytetu Przyrodniczego w Poznaniu. Pomiary, na podstawie których sporządzono diagramy pluwiotermiczne Gaussena-Waltera (ryc. 3), zebrano w tabelach 1 i 2. Daty rozpoczęcia fenologicznych pór roku w Poznaniu, pozyskane z Instytutu Meteorologii i Gospodarki Wodnej Państwowego Instytutu Badawczego,

Tabela 3. Fenologiczne pory roku w Poznaniu w 2017 roku Table 3. Phenological seasons in Poznań in 2017

\begin{tabular}{|c|c|c|c|}
\hline $\begin{array}{l}\text { Fenologiczna pora roku } \\
\text { Phenological season }\end{array}$ & $\begin{array}{c}\text { Roślina wskaźnikowa/pogoda } \\
\text { Indicator plant/weather }\end{array}$ & $\begin{array}{c}\text { Faza } \\
\text { Phase }\end{array}$ & $\begin{array}{l}\text { Data początku } \\
\text { Onset date }\end{array}$ \\
\hline \multirow[t]{2}{*}{$\begin{array}{l}\text { Zaranie wiosny } \\
\text { Beginning of spring }\end{array}$} & Corylus avellana $\mathrm{L}$. & $\begin{array}{l}\text { zakwitanie } \\
\text { beginning of flowering }\end{array}$ & \multirow{2}{*}{07.03} \\
\hline & Tussilago farfara L. & $\begin{array}{l}\text { zakwitanie } \\
\text { beginning of flowering }\end{array}$ & \\
\hline \multirow[t]{2}{*}{$\begin{array}{l}\text { Wczesna wiosna } \\
\text { Early spring }\end{array}$} & Taraxacum officinale F.H. Wigg. & $\begin{array}{l}\text { zakwitanie } \\
\text { beginning of flowering }\end{array}$ & \multirow{2}{*}{03.04} \\
\hline & Betula pendula Roth & $\begin{array}{l}\text { początek listnienia } \\
\text { onset of foliation }\end{array}$ & \\
\hline \multirow[t]{2}{*}{$\begin{array}{l}\text { Pełnia wiosny } \\
\text { Full spring }\end{array}$} & Syringa vulgaris $\mathrm{L}$. & $\begin{array}{l}\text { zakwitanie } \\
\text { beginning of flowering }\end{array}$ & \multirow[b]{2}{*}{06.05} \\
\hline & Aesculus hippocastanum $\mathrm{L}$. & $\begin{array}{l}\text { zakwitanie } \\
\text { beginning of flowering }\end{array}$ & \\
\hline $\begin{array}{l}\text { Wczesne lato } \\
\text { Early summer }\end{array}$ & Robinia pseudoacacia L. & $\begin{array}{l}\text { zakwitanie } \\
\text { beginning of flowering }\end{array}$ & 22.05 \\
\hline $\begin{array}{l}\text { Lato } \\
\text { Summer }\end{array}$ & Tilia cordata Mill. & $\begin{array}{l}\text { zakwitanie } \\
\text { beginning of flowering }\end{array}$ & 12.06 \\
\hline \multirow[t]{3}{*}{$\begin{array}{l}\text { Wczesna jesień } \\
\text { Early autumn }\end{array}$} & Corylus avellana $\mathrm{L}$. & $\begin{array}{l}\text { dojrzewanie owoców } \\
\text { fruit ripening }\end{array}$ & \multirow{3}{*}{07.09} \\
\hline & Aesculus hippocastanum L. & $\begin{array}{l}\text { dojrzewanie owoców } \\
\text { fruit ripening }\end{array}$ & \\
\hline & Calluna vulgaris (L.) Hull & $\begin{array}{l}\text { zakwitanie } \\
\text { beginning of flowering }\end{array}$ & \\
\hline \multirow[t]{3}{*}{$\begin{array}{l}\text { Jesień } \\
\text { Autumn }\end{array}$} & Aesculus hippocastanum L. & $\begin{array}{l}\text { żółknięcie liści } \\
\text { leaf yellowing }\end{array}$ & \multirow{3}{*}{26.10} \\
\hline & Tilia cordata Mill. & $\begin{array}{l}\text { żółknięcie i opadanie liści } \\
\text { leaf yellowing and leaf fall }\end{array}$ & \\
\hline & Betula pendula Roth & $\begin{array}{l}\text { żółknięcie i opadanie liści } \\
\text { leaf yellowing and leaf fall }\end{array}$ & \\
\hline Zima & trzy kolejno następujące po sobie dni z maksymalną temperatu- & & \\
\hline Winter & $\begin{array}{l}\text { rą powietrza poniżej } 0^{\circ} \mathrm{C} \\
\text { three consecutive days with maximum air temperature below } \\
0^{\circ} \mathrm{C}\end{array}$ & - & $-^{*}$ \\
\hline
\end{tabular}

*Fenologiczna zima rozpoczęła się w 2018 roku.

*Phenological winter started in 2018. 
Tabela 4. Daty pojawów fenologicznych faz rozwoju liści w 2017 roku

Table 4. Dates of phenological symptoms for phases of vegetative development in 2017

\begin{tabular}{|c|c|c|c|c|c|c|c|c|}
\hline \multirow{2}{*}{$\begin{array}{l}\text { Gatunek } \\
\text { Species }\end{array}$} & \multicolumn{8}{|c|}{$\begin{array}{c}\text { Fazy rozwoju liści } \\
\text { Phases of leaf development }\end{array}$} \\
\hline & 1 & 2 & 3 & 4 & 5 & 6 & 7 & 8 \\
\hline A. buergerianum & 22.03 & 03.04 & 11.10 & 17.10 & 23.10 & - & 16.10 & 17.11 \\
\hline A. campestre & 15.03 & 27.04 & 04.10 & 12.10 & 03.11 & - & 13.10 & 09.11 \\
\hline A. capillipes & 20.03 & 13.04 & 11.10 & 20.10 & 02.11 & - & 16.10 & 08.11 \\
\hline A. cappadocicum & 22.03 & 19.04 & 05.10 & 10.10 & 16.10 & - & 10.10 & 06.11 \\
\hline A. carpinifolium & 23.03 & 21.04 & 30.10 & 06.11 & 09.11 & - & 06.11 & 22.11 \\
\hline A. circinatum & 13.03 & 12.04 & 30.08 & 25.09 & 17.10 & - & 12.09 & 03.11 \\
\hline A. cissifolium ${ }^{\pi}$ & 03.04 & 08.05 & 02.10 & 13.10 & 31.10 & - & 17.10 & 10.11 \\
\hline A. cissifolium $ᄋ$ & 20.03 & 10.04 & 08.09 & 04.10 & 16.10 & - & 06.10 & 30.10 \\
\hline A. davidii & 20.03 & 13.04 & 02.10 & 07.10 & 14.11 & - & 16.10 & 20.11 \\
\hline A. diabolicum & 24.03 & 15.05 & 25.09 & 10.10 & 23.10 & - & 09.10 & 26.10 \\
\hline A. griseum : & 03.05 & 15.05 & 06.10 & 12.10 & 20.10 & - & 16.10 & 17.11 \\
\hline A. griseum :ơ: & 10.04 & 09.05 & 13.10 & 23.10 & 31.10 & - & 17.10 & 21.11 \\
\hline A. japonicum & 10.03 & 11.04 & 02.10 & 27.10 & 03.11 & - & 24.10 & 21.11 \\
\hline A. maximowiczianum & 31.03 & 27.04 & 12.10 & 19.10 & 25.10 & - & 25.10 & 15.11 \\
\hline A. miyabei & 03.04 & 11.05 & 22.09 & 11.10 & 14.11 & - & 26.09 & 17.10 \\
\hline A. mono & 17.03 & 20.04 & 29.09 & 23.10 & 31.10 & - & 02.10 & 20.11 \\
\hline A. palmatum & 23.03 & 13.04 & 18.09 & 26.09 & 02.11 & - & 13.10 & 17.11 \\
\hline A. platanoides & 13.03 & 12.04 & 10.10 & 19.10 & 03.11 & - & 17.10 & 15.11 \\
\hline A. rubrum & 06.03 & 13.04 & 13.10 & 16.10 & 31.10 & - & 16.10 & 08.11 \\
\hline A. rufinerve & 31.03 & 08.05 & 13.10 & 19.10 & 24.10 & - & 16.10 & 10.11 \\
\hline A. saccharum & 29.03 & 12.04 & 20.09 & 26.09 & 02.10 & - & 26.09 & 16.10 \\
\hline A. shirasawanum & 28.03 & 28.04 & 11.10 & 16.10 & 23.10 & - & 16.10 & 27.10 \\
\hline A. stachyophyllum & 20.03 & 05.04 & 01.09 & 17.10 & 07.11 & - & 05.09 & 20.11 \\
\hline A. tataricum & 17.03 & 04.04 & 29.09 & 10.10 & 30.10 & - & 04.10 & 15.11 \\
\hline A. tataricum ssp. ginnala & 22.03 & 03.04 & 02.10 & 13.10 & 26.10 & - & 05.10 & 13.11 \\
\hline A. truncatum & 07.03 & 03.04 & 13.10 & 16.10 & 25.10 & - & 16.10 & 30.10 \\
\hline
\end{tabular}

Numery 1-8 odpowiadają fazom rozwojowym opisanym w rozdziale Teren badań, materiał i metody; - nie stwierdzono występowania fazy 6. (utrata dekoracyjnego zabarwienia liści jesienia).

Numbers 1-8 correspond to development phases described in Study area, material and methods; - phase no. 6 not found in analysed maples (loss of decorative autumn foliage).

Tabela 5. Daty pojawów fenologicznych faz rozwoju kwiatów w 2017 roku

Table 5. Dates of phenological symptoms for phases of flower development in 2017

\begin{tabular}{|c|c|c|c|c|c|c|c|}
\hline \multirow{2}{*}{$\begin{array}{l}\text { Gatunek } \\
\text { Species }\end{array}$} & \multicolumn{7}{|c|}{$\begin{array}{c}\text { Fazy rozwoju kwiatów } \\
\text { Phases of flower development }\end{array}$} \\
\hline & 9 & 10 & 11 & 12 & 13 & 14 & 15 \\
\hline A. buergerianum & - & - & - & - & - & - & - \\
\hline A. campestre & 18.04 & 24.04 & 26.04 & 15.05 & 17.05 & 08.05 & 19.05 \\
\hline A. capillipes & 13.04 & 15.05 & 22.05 & 25.05 & 29.05 & 25.05 & 01.06 \\
\hline A. cappadocicum & 20.04 & 27.04 & 03.05 & 08.05 & 16.05 & 09.05 & 19.05 \\
\hline A. carpinifolium & 05.05 & 08.05 & 09.05 & 15.05 & 16.05 & 09.05 & 18.05 \\
\hline A. circinatum & 05.04 & 10.04 & 12.04 & 24.04 & 05.05 & 18.04 & 09.05 \\
\hline A. cissifolium $\widehat{\widehat{O}}$ & 21.04 & 01.05 & 03.05 & 16.05 & 23.05 & 12.05 & 29.05 \\
\hline A. cissifolium + & 04.04 & 07.04 & 10.04 & 19.04 & 24.04 & 13.04 & 27.04 \\
\hline A. davidii & 13.04 & 15.05 & 16.05 & 23.05 & 25.05 & 18.05 & 26.05 \\
\hline A. diabolicum & - & - & - & - & - & - & - \\
\hline A. griseum & 05.05 & 15.05 & 17.05 & 18.05 & 22.05 & 19.05 & 23.05 \\
\hline A. griseum :ơ: & 21.04 & 01.05 & 05.05 & 12.05 & 15.05 & 08.05 & 17.05 \\
\hline A. japonicum & 06.04 & 11.04 & 14.04 & 24.04 & 05.05 & 18.04 & 08.05 \\
\hline A. maximowiczianum & 24.04 & 27.04 & 02.05 & 11.05 & 16.05 & 12.05 & 18.05 \\
\hline A. miyabei & 15.05 & 16.05 & 19.05 & 23.05 & 25.05 & 24.05 & 29.05 \\
\hline A. mono & 03.04 & 11.04 & 13.04 & 18.04 & 20.04 & 14.04 & 05.05 \\
\hline A. palmatum & 06.04 & 20.04 & 28.04 & 08.05 & 17.05 & 08.05 & 19.05 \\
\hline A. platanoides & 31.03 & 03.04 & 04.04 & 13.04 & 18.04 & 04.04 & 25.04 \\
\hline A. rubrum & 24.03 & 27.03 & 28.03 & 31.03 & 03.04 & 31.03 & 10.04 \\
\hline A. rufinerve & 24.04 & 27.04 & 02.05 & 12.05 & 15.05 & 03.05 & 18.05 \\
\hline A. saccharum & - & - & - & - & - & - & - \\
\hline A. shirasawanum & 02.05 & 08.05 & 12.05 & 16.05 & 17.05 & 15.05 & 22.05 \\
\hline A. stachyophyllum & 03.04 & 06.04 & 10.04 & 25.04 & 09.05 & 13.04 & 11.05 \\
\hline A. tataricum & 06.04 & 15.05 & 18.05 & 23.05 & 31.05 & 24.05 & 06.06 \\
\hline A. tataricum ssp. ginnala & 06.04 & 15.05 & 18.05 & 23.05 & 26.05 & 23.05 & 01.06 \\
\hline A. truncatum & 03.04 & 06.04 & 11.04 & 20.04 & 03.05 & 18.04 & 12.05 \\
\hline
\end{tabular}

Numery 9-15 odpowiadają fazom rozwojowym opisanym w rozdziale Teren badań, materiał i metody; - klon nie zakwitł.

Numbers 9-15 correspond to development phases described in Study area, material and methods; - maple did not bloom. 
Tabela 6. Daty pojawów fenologicznych faz rozwoju owoców w 2017 roku

Table 6. Dates of phenological symptoms for phases of fruit development in 2017

\begin{tabular}{|c|c|c|c|c|c|c|}
\hline \multirow{2}{*}{$\begin{array}{l}\text { Gatunek } \\
\text { Species }\end{array}$} & \multicolumn{6}{|c|}{$\begin{array}{c}\text { Fazy rozwoju owoców } \\
\text { Phases of fruit development }\end{array}$} \\
\hline & 16 & 17 & 18 & 19 & 20 & 21 \\
\hline A. buergerianum & - & - & - & - & - & - \\
\hline A. campestre & 31.08 & 07.09 & 05.10 & 25.09 & 18.10 & $\rightarrow^{2018}$ \\
\hline A. capillipes & 19.09 & 02.10 & 13.10 & 20.10 & 31.10 & $\rightarrow^{2018}$ \\
\hline A. cappadocicum & 05.09 & 13.09 & 25.09 & 02.10 & 04.10 & 10.11 \\
\hline A. carpinifolium & 04.10 & 13.10 & 20.10 & 26.10 & 14.11 & $\rightarrow^{2018}$ \\
\hline A. circinatum & 14.08 & 28.08 & 15.09 & 31.08 & 29.09 & $\rightarrow^{2018}$ \\
\hline A. cissifolium $\supsetneq$ & 06.09 & 15.09 & 25.09 & 21.09 & 15.11 & $\rightarrow^{2018}$ \\
\hline A. davidii & 09.10 & 16.10 & 23.10 & 13.10 & 30.10 & $\rightarrow^{2018}$ \\
\hline A. diabolicum & - & - & - & - & - & - \\
\hline A. griseum & 11.09 & 21.09 & 26.09 & 29.09 & 04.10 & $\rightarrow^{2018}$ \\
\hline A. griseum :ợ: & 04.09 & 08.09 & 15.09 & 19.09 & 02.10 & 03.11 \\
\hline A. japonicum & 14.08 & 24.08 & 18.09 & 22.09 & 03.10 & 16.11 \\
\hline A. maximowiczianum & 15.09 & 22.09 & 26.09 & $*$ & $*$ & $*$ \\
\hline A. miyabei & $* *$ & $* *$ & $* *$ & $* *$ & $* *$ & $* *$ \\
\hline A. mono & $* * *$ & $* * *$ & $* * *$ & $* * *$ & $* * *$ & $* * *$ \\
\hline A. palmatum & 26.09 & 02.10 & 10.10 & 04.10 & 09.10 & $\rightarrow^{2018}$ \\
\hline A. platanoides & 18.09 & 03.10 & 13.10 & 10.10 & 30.10 & 29.11 \\
\hline A. rubrum & $* * *$ & $* * *$ & $* * *$ & $* * *$ & $* * *$ & $* * *$ \\
\hline A. rufinerve & $* * *$ & $* * *$ & $* * *$ & $* * *$ & $* * *$ & $* * *$ \\
\hline A. saccharum & - & - & - & - & - & - \\
\hline A. shirasawanum & $* *$ & $* *$ & $* *$ & $* *$ & $* *$ & $* *$ \\
\hline A. stachyophyllum & $* *$ & $* *$ & $* *$ & $* *$ & $* *$ & $* *$ \\
\hline A. tataricum & 17.08 & 23.08 & 28.08 & 29.09 & 18.10 & $\rightarrow^{2018}$ \\
\hline A. tataricum ssp. ginnala & 17.08 & 22.08 & 28.08 & 05.10 & 16.10 & $\rightarrow^{2018}$ \\
\hline A. truncatum & 29.08 & 08.09 & 12.09 & 06.09 & 11.09 & 18.09 \\
\hline
\end{tabular}

Numery 16-21 odpowiadają fazom rozwojowym opisanym w rozdziale Teren badań, materiał i metody; - klon nie zakwitł; *rozsiewanie nie odbyło się w roku obserwacji; ${ }^{* *}$ wszystkie owoce opadły przed dojrzeniem; ${ }^{* * *}$ klon nie zawiązał owoców; $\rightarrow{ }^{2018}$ rozsiewanie przeciągnęło się do następnego roku.

Numbers 16-21 correspond to development phases described in Study area, material and methods; - maple not bloomed; *dispersal did not take place in the year of observation; **all fruits fell before ripening; ${ }^{* * *}$ maple did not set fruits; $\rightarrow{ }^{2018}$ dispersal was extended to the following year.

pochodzą $\mathrm{z}$ obserwacji prowadzonych $\mathrm{w}$ okolicy stacji Poznań Ławica. Dodatkowo okres zimy został wyznaczony za ŁUKASIEWICZEM i GóRSKĄ-ZAJĄCZKOWSKĄ (1983), a jego początek jest równoznaczny z nastaniem trzech kolejno następujących po sobie dni, w których maksymalna temperatura powietrza spada poniżej $0^{\circ} \mathrm{C}$. Dane te, zebrane w tabeli 3, posłużyły jako tło w graficznym przedstawieniu wyników badań.

\section{WYNIKI}

Wyniki przeprowadzonych obserwacji fenologicznych zebrano w tabelach 4-6. Dodatkowo zilustrowano je $\mathrm{w}$ postaci spektrów fenologicznych (ryc. 4-7). Na rycinach 8-9 przedstawiono zdjęcia liści badanych klonów w okresie letnim oraz $\mathrm{w}$ okresie jesiennego przebarwiania. W zdecydowanej większości liście klonów nie stawały się nieestetyczne przed opadnięciem. Wyjątek stanowią A. capillipes, A circinatum, A. rubrum i A. tataricum, które równocześnie z przebarwianiem się liści, stawały się nieatrakcyjne ze względu na brązowe nekrotyczne plamy. W przypadku badanych klonów nie stwierdzono utraty dekoracyjnego zabarwienia liści (fenofaza oznaczona numerem 6).

W tabeli 7 badanym gatunkom klonów przypisano inne właściwości ozdobne, pokazane na rycinie 10.
Analiza warunków klimatycznych wskazuje na chłodniejszy początek zimy, wyraźnie cieplejsze: zaranie wiosny, początek lata i jesień 2017 roku w stosunku do średnich temperatur dziesięciolecia 2007-2016. W roku obserwacji nie wystąpił okres suszy, a ponadto suma opadów była znacząco większa od średniej z poprzedzającego go dziesięciolecia; opady w okresie pełni lata i jesienią były wyraźnie większe. Można zatem przypuszczać, że klony w okresie badań nie były narażone na warunki stresowe związane $z$ niedoborem wody.

\section{DYSKUSJA}

Spośród wszystkich badanych gatunków klonów A. buergerianum, $A$. diabolicum i $A$. saccharum nie zakwitły. Jak podaje ŁUKASIEWICZ (1993), klon Buergera oraz klon kosmaty kwitły i owocowały już wielokrotnie w Ogrodzie Botanicznym UAM. Należy przy tym zaznaczyć, że w niniejszej pracy obserwowano te same drzewa, o których wspomina ŁuKASIEwICZ (1993). Acer buergerianum znajduje się w kolekcji już od ponad 60 lat. Jest to drzewo rosnące na stanowisku zacienionym, cechujące się słabo wykształconą koroną. Można zakładać, że w latach osiemdziesiątych XX wieku, gdy obserwacje na klonach prowadził ŁUKASIEWICZ (1993), sąsiadujące drzewa nie były 


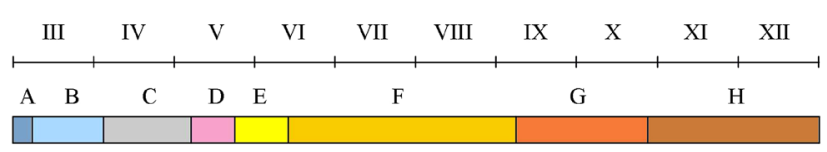

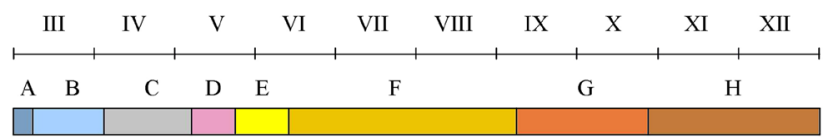
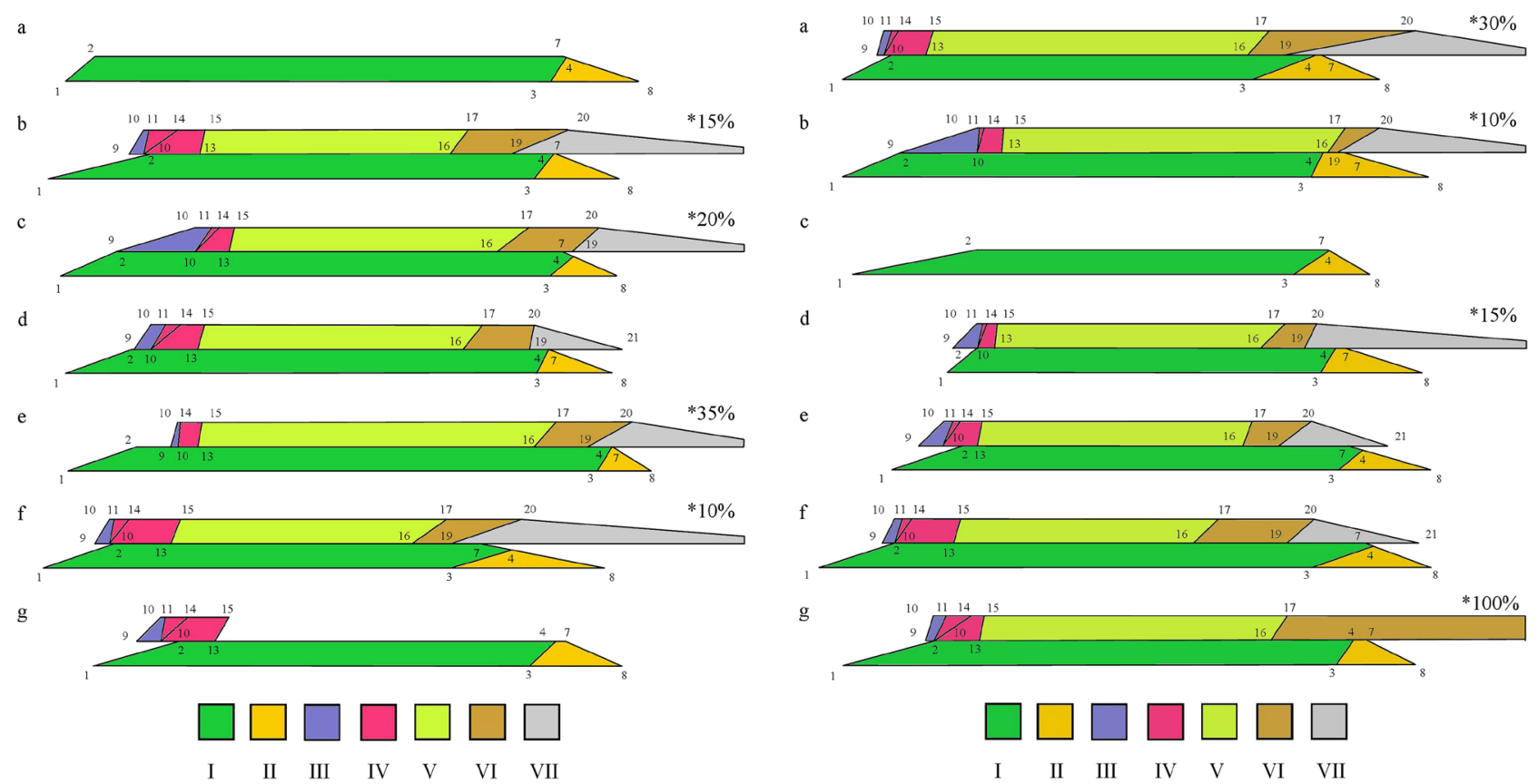

Ryc. 4. Spektra fenologiczne: A. buergerianum (a), A. campestre (b), A. capillipes (c), A. cappadocicum (d), A. carpinifolium (e), A. circinatum ( $\mathrm{f}$, A. cissifolium ô (g)

Numery 1-21 odpowiadają fazom rozwojowym opisanym w rozdziale Teren badań, materiał i metody oraz numerom faz rozwojowych ujętych w tabelach 4-6.

A - zima, B - zaranie wiosny, C - wczesna wiosna, D - pełna wiosna, E - wczesne lato, F - lato, G - wczesna jesień, H - jesień; fazy: I - listnienia, II - przebarwiania i opadania liści, III - pąków kwiatostanowych, IV - kwitnienia, V - owoców niedojrzałych, VI - owoców dojrzałych, VII - rozsiewania owoców; * - ilość owoców pozostałych na krzewie/drzewie.

Fig. 4. Phenological spectra: A. buergerianum (a), A. campestre (b), A. capillipes (c), A. cappadocicum (d), A. carpinifolium (e), A. circinatum (f), A. cissifolium ơ (g)

Numbers 1-21 correspond to development phases described in Study area, material and methods and the numbers of development phases given in Tables 4-6.

A - winter, B - beginning of spring, C - early spring, D - full spring, E - early summer, F - summer, G - early autumn, $\mathrm{H}$ - autumn; stages: I - foliation, II - autumn leaf coloration and leaf-fall, III - inflorescence buds, IV - flowering, V - immature fruits, VI mature fruits, VII - fruits dispersion $;^{*}$ - percentage of the fruits left on the bush/tree.

jeszcze tak rozrośnięte jak obecnie. Klon miał zatem większy dostęp do światła, a przy tym był okazem młodszym, bardziej witalnym, co mogło sprawić, że przechodził pełną fazę generatywną. W przypadku A. diabolicum i A. saccharum przyczyną braku kwitnienia mogły być niekorzystne warunki atmosferyczne w okresie zawiązywania pąków kwiatowych. Przeprowadzenie wieloletnich badań nad wymienionymi klonami pozwoliłoby na obserwację wzrostu i rozwoju roślin $\mathrm{w}$ różnorodnych warunkach klimatycznych, co mogłoby pomóc w wytłumaczeniu tego zjawiska. Warto nadmienić, że obydwa drzewa wydają

Ryc. 5. Spektra fenologiczne: A. cissifolium ㅇ (a), A. davidii

(b), A. diabolicum (c), A. griseum : (d), A. griseum :ọ: (e), A. japonicum (f), A. maximowiczianum (g)

Numery 1-21 odpowiadają fazom rozwojowym opisanym w rozdziale Teren badań, materiał i metody oraz numerom faz rozwojowych ujętych w tabelach 4-6.

A - zima, B - zaranie wiosny, C - wczesna wiosna, D - pełna wiosna, E - wczesne lato, F - lato, G - wczesna jesień, H - jesień; fazy: I - listnienia, II - przebarwiania i opadania liści, III - pąków kwiatostanowych, IV - kwitnienia, V - owoców niedojrzałych, VI - owoców dojrzałych, VII - rozsiewania owoców; * - ilość owoców pozostałych na krzewie/drzewie.

Fig. 5. Phenological spectra: A. cissifolium $\bigcirc$ (a), A. davidii (b), A. diabolicum (c), A. griseum :ọ: (d), A. griseum :ờ: (e), A. japonicum (f), A. maximowiczianum (g)

Numbers 1-21 correspond to development phases described in Study area, material and methods and the numbers of development phases given in Tables 4-6.

A - winter, B - beginning of spring, C - early spring, D - full spring, E - early summer, F - summer, G - early autumn, $\mathrm{H}$ - autumn; stages: I - foliation, II - autumn leaf coloration and leaf-fall, III - inflorescence buds, IV - flowering, V - immature fruits, VI - mature fruits, VII - fruits dispersion; * - percentage of the fruits left on the bush/tree.

się $\mathrm{w}$ pełni zdrowe, odznaczają się dobrze rozwiniętą koroną oraz mają zapewniony dostęp do światła.

Wartość dekoracyjna kwiatów klonów nie jest szczególnie duża $\mathrm{w}$ porównaniu $\mathrm{z}$ innymi gatunkami roślin, które kwitną w tym samym okresie. Warto jednak wziąć pod uwagę klon zwyczajny A. platanoides, jako szczególnie wartościowy pod tym względem. Kwitnie on przed rozwojem liści i na ogół bardzo obficie. Na szczególną uwagę zasługuje $A$. davidii, który cechuje się wyjątkowo dekoracyjnymi kwiatami w stosunku do innych badanych klonów. Jego długie, 


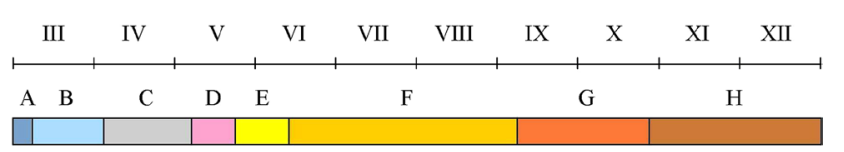

\begin{tabular}{|c|c|c|c|c|c|c|c|c|c|c|}
\hline I & & IV & V & & VII & VIII & IX & $X$ & XI & XII \\
\hline A & B & C & D & E & & & & G & & $\mathrm{H}$ \\
\hline
\end{tabular}
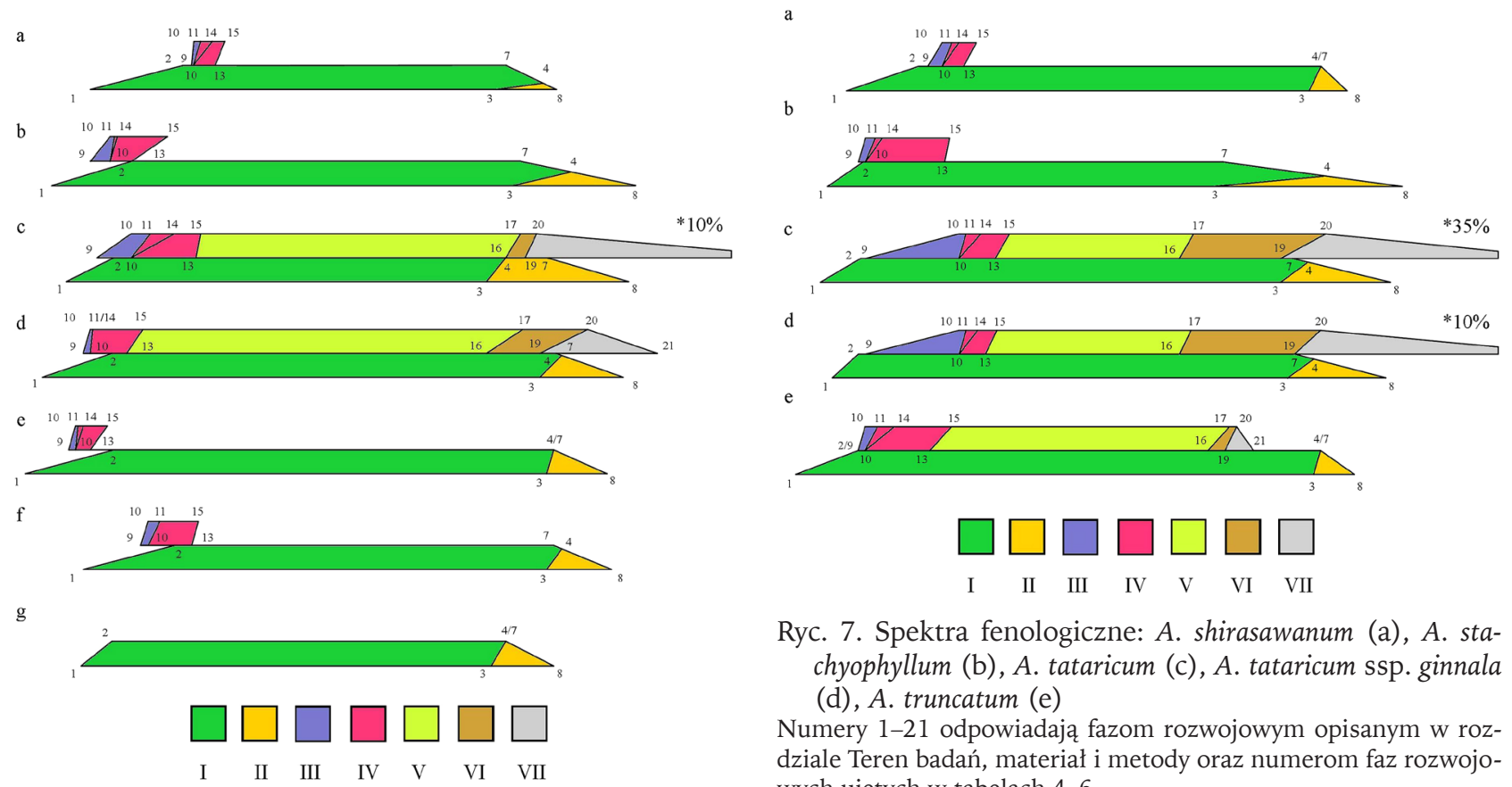

Ryc. 7. Spektra fenologiczne: A. shirasawanum (a), A. stachyophyllum (b), A. tataricum (c), A. tataricum ssp. ginnala (d), A. truncatum (e)

Numery 1-21 odpowiadają fazom rozwojowym opisanym w rozdziale Teren badań, materiał i metody oraz numerom faz rozwojowych ujętych w tabelach 4-6.

Ryc. 6. Spektra fenologiczne: A. miyabei (a), A. mono (b), A. palmatum (c), A. platanoides (d), A. rubrum (e), A. rufinerve (f), A. saccharum (g)

Numery 1-21 odpowiadają fazom rozwojowym opisanym w rozdziale Teren badań, materiał i metody oraz numerom faz rozwojowych ujętych w tabelach 4-6.

A - zima, B - zaranie wiosny, C - wczesna wiosna, D - pełna wiosna, E - wczesne lato, F - lato, G - wczesna jesień, H - jesień; fazy: I - listnienia, II - przebarwiania i opadania liści, III - packów kwiatostanowych, IV - kwitnienia, V - owoców niedojrzałych, VI - owoców dojrzałych, VII - rozsiewania owoców; * - ilość owoców pozostałych na krzewie/drzewie.

Fig. 6. Phenological spectra: A. miyabei (a), A. mono (b), A. palmatum (c), A. platanoides (d), A. rubrum (e), A. rufinerve ( $\mathrm{f}$ ), A. saccharum ( $\mathrm{g}$ )

Numbers 1-21 correspond to development phases described in Study area, material and methods and the numbers of development phases given in Tables 4-6.

A - winter, B - beginning of spring, C - early spring, D - full spring, $\mathrm{E}$ - early summer, $\mathrm{F}$ - summer, $\mathrm{G}$ - early autumn, $\mathrm{H}$ - autumn; stages: I - foliation, II - autumn leaf coloration and leaf-fall, III - inflorescence buds, IV - flowering, V - immature fruits, VI - mature fruits, VII - fruits dispersion; ${ }^{*}$ - percentage of the fruits left on the bush/tree.

przewieszające się grona są dobrze widoczne na tle ciemnych liści i nadają drzewu egzotyczny wygląd.

Większość gatunków odznacza się żółtym lub zielonym zabarwieniem kwiatów, co sprawia, że są słabo widoczne na tle rozwijających się lub już rozwiniętych liści. Jak podaje BUGAŁA (2000), klon okrągłolistny A. circinatum i klon japoński A. japonicum cechują się czerwonawymi kwiatami, które są ozdobne w czasie kwitnienia, jednak według nas jest to chwilowy aspekt. Po rozwinięciu się liści niewielkie kwiaty tych klonów pozostają $\mathrm{W}$ większości zakryte, przez co omawiane

A - zima, B - zaranie wiosny, C - wczesna wiosna, D - pełna wiosna, E - wczesne lato, F - lato, G - wczesna jesień, H - jesień; fazy: I - listnienia, II - przebarwiania i opadania liści, III - pąków kwiatostanowych, IV - kwitnienia, V - owoców niedojrzałych, VI - owoców dojrzałych, VII - rozsiewania owoców; * - ilość owoców pozostałych na krzewie/drzewie.

Fig. 7. Phenological spectra: A. shirasawanum (a), A. stachyophyllum (b), A. tataricum (c), A. tataricum ssp. ginnala (d), A. truncatum (e)

Numbers 1-21 correspond to development phases described in Study area, material and methods and the numbers of development phases given in Tables 4-6.

A - winter, B - beginning of spring, C - early spring, D - full spring, E - early summer, F - summer, G - early autumn, $\mathrm{H}$ - autumn; stages: I - foliation, II - autumn leaf coloration and leaf-fall, III - inflorescence buds, IV - flowering, V - immature fruits, VI - mature fruits, VII - fruits dispersion; ${ }^{*}$ - percentage of the fruits left on the bush/tree.

drzewa nie wyróżniają się na tle innych roślin. Poza wymienionymi $A$. platanoides i $A$. davidii klony powinny być popularyzowane nie pod względem dekoracyjności kwiatów, lecz pod kątem ich przydatności w pszczelarstwie, o której informuje LIPIŃSKI (2010).

W roku obserwacji prócz klonów niekwitnących (A. buergerianum, A. diabolicum i A. saccharum) owoców nie zawiązały: A. mono, A. rubrum i A. rufinerve. TumiŁowicz i SzymczAK (1997) wspominają, że A. rubrum w Arboretum SGGW w Rogowie przechodzi pełen cykl generatywny, wydając przy tym płodne nasiona i odnawiając się samosiewnie. Proces ten, jak twierdzą CHYLARECKi i StRaus (1968), świadczy o zaadaptowaniu się rośliny do danych warunków klimatycznych, można zakładać, że w przypadku badanego okazu brak owocowania nie wynika $z$ braku adaptacji 


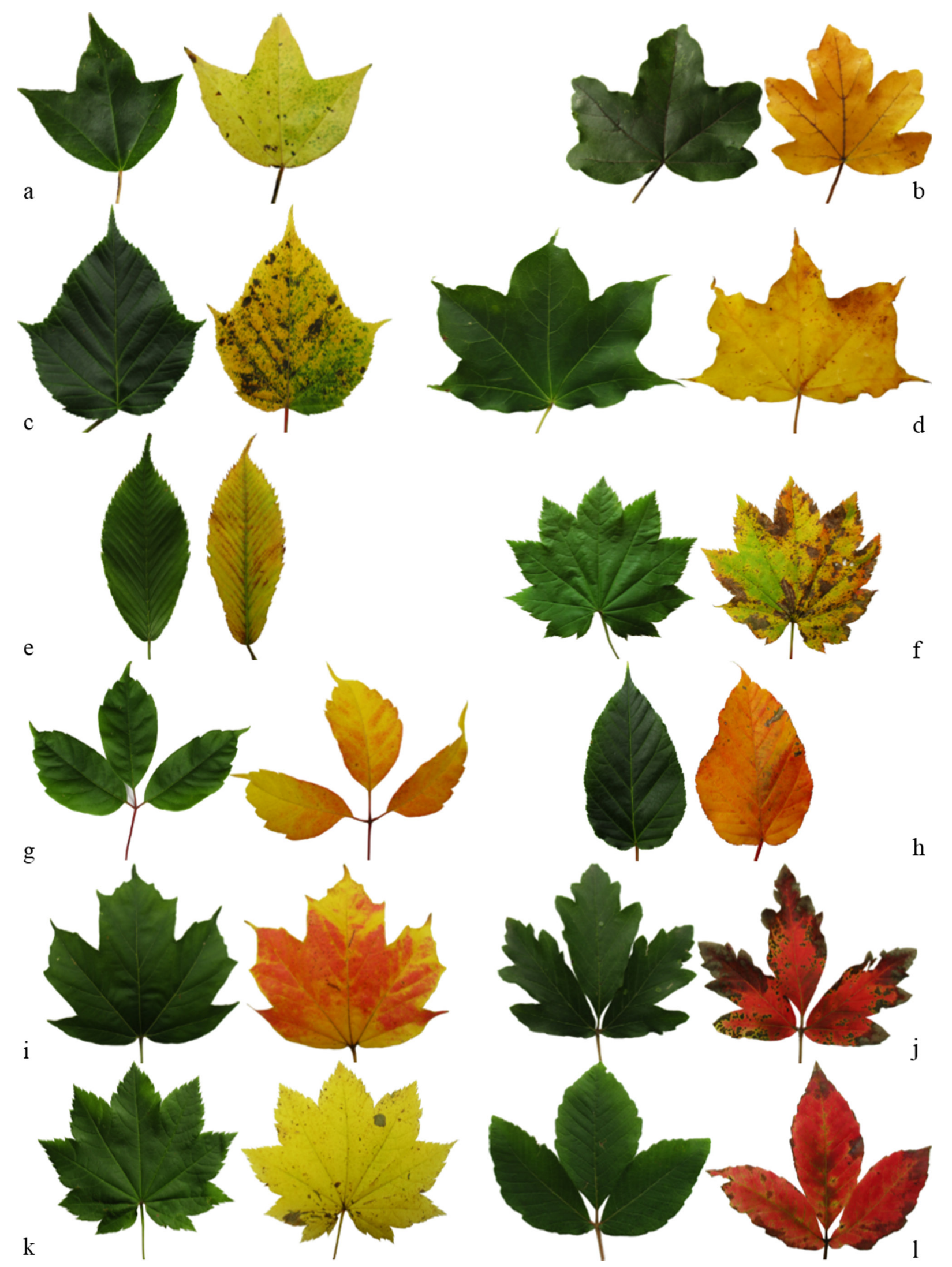

Ryc. 8. Liście A. buergerianum (a), A. campestre (b), A. capillipes (c), A. cappadocicum (d), A. carpinifolium (e), A. circinatum (f), A. cissifolium (g), A.davidii (h), A. diabolicum (i), A. griseum (j), A. japonicum (k), A. maximowiczianum (l) w okresie letnim i jesiennego przebarwienia (fot. M. Sowelo)

Fig. 8. Leaves of A. buergerianum (a), A. campestre (b), A. capillipes (c), A. cappadocicum (d), A. carpinifolium (e), A. circinatum (f), A. cissifolium (g), A. davidii (h), A. diabolicum (i), A. griseum (j), A. japonicum (k), A. maximowiczianum (l) in summer and of autumn leaf colour change (photo M. Sowelo) 

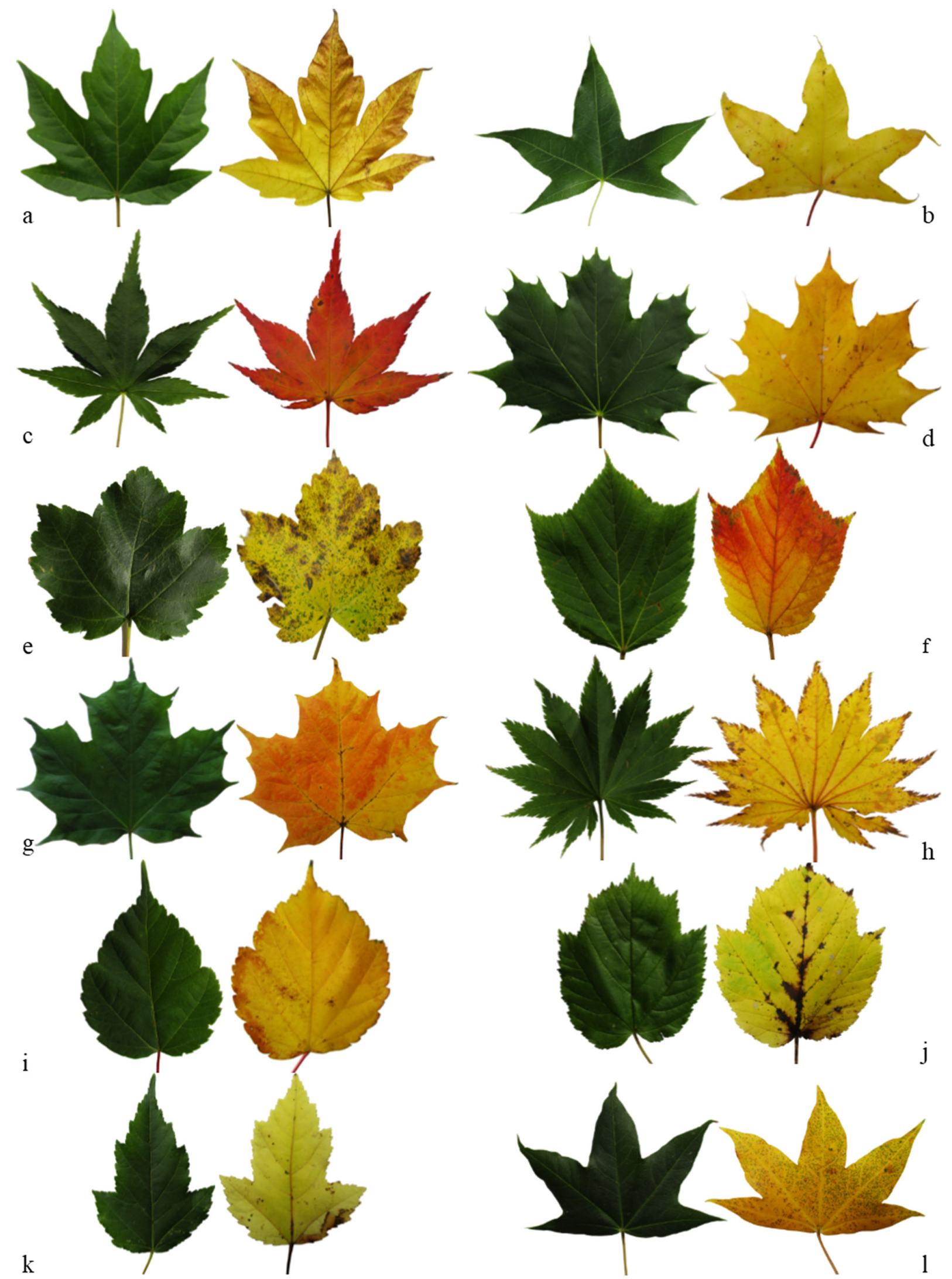

Ryc. 9. Liście A. miyabei (a), A. mono (b), A. palmatum (c), A. platanoides (d), A. rubrum (e), A. rufinerve (f), A. saccharum (g), A. shirasawanum (h), A. stachyophyllum (i), A. tataricum (j), A. tataricum ssp. ginnala (k), A. truncatum (l) w okresie letnim i jesiennego przebarwienia (fot. M. Sowelo)

Fig. 9. Leaves of A. miyabei (a), A. mono (b), A. palmatum (c), A. platanoides (d), A. rubrum (e), A. rufinerve (f), A. saccharum (g), A. shirasawanum (h), A. stachyophyllum (i), A. tataricum (j), A. tataricum ssp. ginnala (k), A. truncatum (l) in summer and of autumn leaf colour change (photo M. Sowelo) 


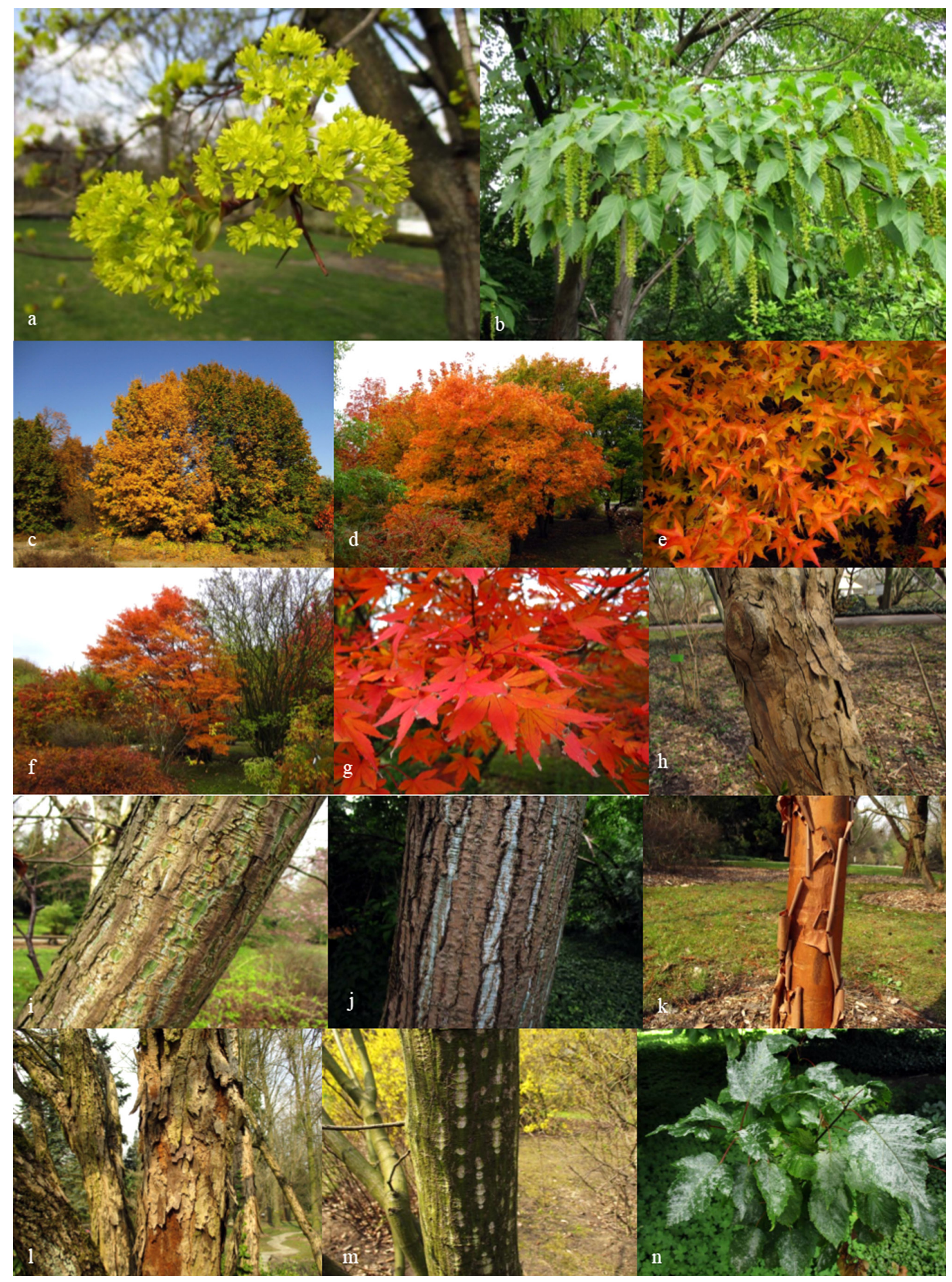

Ryc. 10. Pełnia kwitnienia A. platanoides (a) oraz koniec kwitnienia A. davidii (b); jesienne zabarwienie liści u A. campestre (c), A. miyabei (d, e) oraz A. palmatum (f, g); dekoracyjna korowina u A. buergerianum (h), A. capillipes (i), A. davidii (j), A. griseum (k), A. miyabei (l) i A. rufinerve (m); mączniak prawdziwy na liściach A. tataricum ssp. ginnala (n)

Fig. 10. Full anthesis A. platanoides (a) end of the flowering A. davidii (b); autumn foliage of A. campestre (c), A. miyabei (d, e) and A. palmatum (f, g); attractive bark of A. buergerianum (h), A. capillipes (i), A. davidii (j), A. griseum (k), A. miyabei (l) and A. rufinerve (m); a powdery mildew on the leaves A. tataricum ssp. ginnala (n) 
Tabela 7. Zestawienie klonów według różnych cech zdobniczych

Table 7 . The list of maples according to the different ornamental features

\begin{tabular}{|c|c|c|c|c|c|}
\hline $\begin{array}{l}\text { Gatunek } \\
\text { Species }\end{array}$ & $\begin{array}{l}\text { Efektowne kwiaty } \\
\text { lub obfite kwitnienie } \\
\text { Spectacular flowers or } \\
\text { abundant flowering }\end{array}$ & $\begin{array}{l}\text { Dekoracyj- } \\
\text { ne owoce } \\
\text { Decorative } \\
\quad \text { fruits }\end{array}$ & $\begin{array}{l}\text { Liście intensywnie przebarwiają- } \\
\text { ce się jesienią na żółto, pomarań- } \\
\text { czowo lub czerwono } \\
\text { Autumn leaves intensely colored } \\
\text { in yellow, orange or red }\end{array}$ & $\begin{array}{l}\text { Długi okres list- } \\
\text { nienia ( } \geq 240 \text { dni) } \\
\text { Long foliage peri- } \\
\text { od ( } \geq 240 \text { days })\end{array}$ & $\begin{array}{l}\text { Ozdobna kora } \\
\text { i pędy } \\
\text { Decorative bark } \\
\text { and stems }\end{array}$ \\
\hline A. buergerianum & & & & + & + \\
\hline A. campestre & & & + & & \\
\hline A. capillipes & & + & & & + \\
\hline A. cappadocicum & & & + & & \\
\hline A. carpinifolium & & & + & + & \\
\hline \multicolumn{6}{|l|}{ A. circinatum } \\
\hline A. cissifolium & & & + & & \\
\hline A. davidii & + & + & + & + & + \\
\hline A. diabolicum & & & + & & \\
\hline A. griseum & & & + & & + \\
\hline A. japonicum & & & + & + & \\
\hline A. maximowiczianum & & & + & & \\
\hline A. miyabei & & & + & & + \\
\hline A. mono & & & + & + & \\
\hline A. palmatum & & & + & & \\
\hline A. platanoides & + & & + & + & \\
\hline A. rubrum & & & & + & \\
\hline A. rufinerve & & & + & & + \\
\hline A. saccharum & & & + & & \\
\hline A. shirasawanum & & & + & & \\
\hline A. stachyophyllum & & & + & + & \\
\hline A. tataricum & & + & & + & \\
\hline A. tataricum ssp. ginnala & & + & & & \\
\hline A. truncatum & & & + & & \\
\hline
\end{tabular}

gatunku do warunków panujących w Polsce. Przemawia za tym również to, że - jak podaje TumiŁowicz (2000) za HeinZe i Schreiber (1987) - Poznań znajduje się w cieplejszej strefie klimatycznej (7A) aniżeli Rogów (6B). Brak owocowania klonu czerwonego może wynikać z osłabienia spowodowanego przez jemiołę pospolitą Viscum album L. rosnącą na tym drzewie w liczbie 20 okazów.

ŁUKASIEWICZ (1993) zauważył, że klon mono w latach jego obserwacji cechował się przemiennym owocowaniem lub jego całkowitym brakiem. Niniejsza praca obejmuje badania prowadzone na tym samym okazie po ponad trzydziestu latach. Aby stwierdzić, czy dany egzemplarz rośliny jest nadal zdolny do wydawania owoców, należałoby przeprowadzić obserwacje w latach następnych.

Wśród badanych gatunków klonów znajdują się takie, których jesienne zabarwienie liści jest nad wyraz efektowne. W niektórych krajach poświęca się temu zjawisku znacznie więcej uwagi aniżeli w Polsce. Jak podaje GóRKA (2003), w Stanach Zjednoczonych informuje się w mediach o miejscach, które w danym czasie warto odwiedzić ze względu na jesienny krajobraz. Funkcjonuje również wiele portali internetowych, które każdego roku na bieżąco informują o przebarwiających się roślinach. Istnieje nawet potoczne określenie zjawiska związanego z rzeszą turystów, którzy podróżują i fotografują jesienne barwy - leaf-peeping (Dreiss i Volin 2014). W dosłownym tłumaczeniu jest to „podglądanie liści”. Jeszcze większą popularnością cieszą się jesienne krajobrazy w Japonii, które oprócz festiwalu kwitnącej wiśni hanami, są jednym z ważniejszych zjawisk przyrodniczych w kulturze tego kraju. Ich nazwa to momijigari, co w tłumaczeniu na język polski znaczy „polowanie na klony". Tradycje jesiennego festiwalu swymi korzeniami sięgają tysiąca lat wstecz (FRÉDÉRIC 2005). Momijigari jest okresem, w którym Japończycy podróżują i kontemplują wspaniałe widoki przebarwionych klonów. Warto byłoby również w Polsce spopularyzować taką formę turystyki i aktywnego wypoczynku.

Jesienne zabarwienie liści A. rubrum w ojczyźnie występowania gatunku, tj. Ameryce Północnej, uchodzi za nadzwyczaj efektowne. Blaszki przebarwiają się na kolor od szkarłatnego przez płomiennoczerwony do pomarańczowego (GELDEREN i in. 1995, SENETA i Dolatowski 2012). Również Bugata (1999) uznaje klon czerwony za jeden $z$ najpiękniejszych klonów wywodzących się z Ameryki Północnej, a FraziK-ADAмсZYK (2004) informuje o przebarwianiu się liści kolumnowej odmiany 'Scanlon' na czerwono i pomarańczowo. Jednak, jak zaznaczyli TumiŁowicz (2002) czy Seneta i Dolatowski (2012), w Polsce klon najczęściej wybarwia liście na żółto. Również obserwacje 
poczynione na potrzeby niniejszej pracy wskazuja, że liście tego gatunku w kolekcji Ogrodu przebarwiają się na żółtawy kolor, przy czym pojawiają się również brązowe plamy. Należałoby zatem ostrożnie podchodzić do kwestii zamieszczania $A$. rubrum w zestawieniach roślin atrakcyjnych jesienią. Cenne mogą okazać się obserwacje prowadzone na innych okazach tego gatunku w rozmaitych warunkach na terenie kraju. Bugata (1999) zwraca uwagę na preferencję gatunku w stosunku do odczynu gleby, twierdząc, że na glebach wapiennych klony czerwone słabo rosną, są chorowite i szybciej zamierają. Jak podają Lıs i PASIECZNA (2005), na terenie Poznania przeważają gleby o odczynie alkalicznym, co jest związane m.in. z emisją pyłów przez zakłady przemysłowe i elektrociepłownie. Ogród Botaniczny UAM również znajduje się w tej strefie. Można zatem przypuszczać, że klon czerwony, który preferuje odczyn zbliżony do kwaśnego (Bugata 1999), nie rośnie w optymalnych dla siebie warunkach glebowych. Może to mieć wpływ na odmienne jesienne wybarwienie się liści w stosunku do północnoamerykańskich odpowiedników. Warto przeprowadzić pod tym kątem szczegółowe badania.

Wśród przebadanych gatunków znajdują się klony cechujące się dekoracyjną korowiną. Jest to niewątpliwe dodatkowa wartość zdobnicza, szczególnie cenna w okresie bezlistnym. Jak twierdzi GóRKA (2005), gatunki które mają ozdobną korę i pędy należy szczególnie promować, ponieważ jest to efekt stały w przeciwieństwie do koloru kwiatów czy liści. Do takich gatunków spośród przebadanych można zaliczyć: A. buergerianum, A. capillipes, A. davidii, A. griseum, A. miyabei i A. rufinerve. Spośród wymienionych na szczególną uwagę zasługuje klon Davida, który cechuje się bardzo wyrazistymi białymi, podłużnymi prążkami, oraz klon strzępiastokory A. griseum, którego łuszcząca się cynamonowa korowina jest nad wyraz efektowna.

$\mathrm{Na}$ pięciu obserwowanych klonach stwierdzono występowanie jemioły pospolitej Viscum album. Są nimi: A. diabolicum (1 okaz jemioły), A. miyabei (1 okaz), A. rubrum (20) i A. truncatum (3). Spośród nich tylko klon czerwony wymieniony jest przez BojarczUKA (1971) i STYPIŃSKIEGO (1997) jako żywiciel jemioły. Należałoby zatem przyjąć, że gatunek jest podatny na zasiedlenie przez tego półpasożyta, co w konsekwencji negatywnie rzutuje na jego wartość zdobniczą. W Ogrodzie poza badanym okazem klonu ściętolistnego $A$. truncatum rośnie również drugi egzemplarz tego gatunku, znacznie starszy od obserwowanego. Jest to pokaźnych rozmiarów drzewo, które zostało bardzo mocno zasiedlone przez jemiołę (około 45 okazów). Poczynione obserwacje sugeruja, że A. truncatum można by zakwalifikować jako żywiciela jemioły, jednak należałoby wykonać dodatkowe obserwacje na okazach rosnących $w$ innych kolekcjach dendrologicznych. W przypadku A. diabolicum oraz A. miyabei jest to zbyt niewielka liczba półpasożytów, by móc te gatunki klonów zaliczyć do grona podatnych na zasiedlenie jemiołą. Ponadto w stanie ulistnienia drzew nie jest to na tyle rażące zjawisko, by zaniżyć wartość dekoracyjną wymienionych roślin.

Na klonie tatarskim i Ginnala w roku obserwacji odnotowano liście porażone przez mączniaka prawdziwego. Jak informuje Bugata (1999), jest to grzyb szeroko rozpowszechniony na półkuli północnej, który występuje na klonach. Liście wymienionych gatunków od drugiej połowy sierpnia były bardzo intensywnie pokryte białym nalotem, co wpływało niekorzystnie na ich wartości zdobnicze. Występowanie $\mathrm{w}$ tak dużym natężeniu mączniaka może się wiązać z dość wysokimi opadami w 2017 roku (tab. 1), który na terenie Poznania był rokiem bez okresu suszy. Jednocześnie liście tych klonów nie wybarwiły się jesienią na kolor szkarłatny, o którym wspominają GeLDEREN i in. (1995), tylko na bladożółty. Naszym zdaniem, podatność na mączniaka uniemożliwia zaliczenie $A$. tataricum i $A$. tataricum ssp. ginnala do grupy roślin atrakcyjnych jesienią. Warto jednak zbadać jesienne zabarwienie liści w kolejnych latach i ewentualną korelację z porażeniem przez mączniaka.

\section{PODSUMOWANIE I WNIOSKI}

1. Spośród wszystkich przebadanych gatunków najdłuższym okresem listnienia odznaczają się: A. japonicum (256 dni), A. mono (248 dni) oraz A. platanoides i A. rubrum (247 dni).

2. Klonami cechującymi się najdłużej trwającą fazą jesiennego przebarwiania się liści są: A. stachyophyllum (80 dni), A. circinatum (65 dni), A. palmatum (60 dni) oraz A. mono i okaz żeński A. cissifolium (52 dni).

3. Wśród obserwowanych roślin najdłuższym kwitnieniem wykazały się: A. truncatum (36 dni), A. stachyophyllum (35 dni) oraz A. circinatum i A. palmatum (29 dni).

4. Najbardziej wyróżniającymi się klonami pod względem dekoracyjności kwiatów są $A$. davidii i A. platanoides.

5. Klonami cechującymi się atrakcyjnymi owocami są: A. capillipes, A. davidii, A. tataricum i A. tataricum ssp. ginnala.

6. Wartymi polecenia ze względu na efektowne jesienne zabarwienie liści są: $A$. campestre, A. cappadocicum, A. carpinifolium, A. cissifolium, A. davidii, A. diabolicum, A, griseum, A. japonicum, A. maximowiczianum, A. miyabei, A. mono, A. palmatum, A. platanoides, A. rufinerve, A. saccharum, A. shirasawanum, A. stachyophyllum i A. truncatum.

7. Godnymi polecenia ze względu na ozdobną korowinę i pędy są: A. buergerianum, A. capillipes, $A$. $d a-$ vidii, A. griseum, A. miyabei i A. rufinerve.

8. Warto przeprowadzić wieloletnie obserwacje w celu wytłumaczenia braku kwitnienia A. buergerianum, A. diabolicum i A. saccharum. 
9. Objęcie badaniami w kolejnych latach A. mono, A. rubrum i A rufinerve pomogłoby w ustaleniu, czy klony są zdolne do zawiązywania owoców w warunkach Ogrodu.

10. Przeprowadzenie obserwacji na okazach A. rubrum znajdujących się $\mathrm{w}$ innych kolekcjach na terenie kraju przyczyniłoby się do wyjaśnienia aspektu jesiennego zabarwienia liści tego gatunku.

11. Warto zbadać jesienne zabarwienie liści $A$. tataricum oraz $A$. tataricum ssp. ginnala w kolejnych latach oraz wpływ porażenia mączniakiem prawdziwym na to zjawisko.

\section{LITERATURA}

BiaŁOBoK S. (1971): O naukowej i praktycznej roli badań fenologicznych w ogrodach botanicznych i arboretach. W: S. Pieniążek (red.). Fenologia i jej praktyczne wykorzystanie. Materiały z obrad Zjazdu Fenologicznego. Kraków, 15-16 czerwca 1970. Zeszyty Problemowe Postępów Nauk Rolniczych 120: 83-91.

Bielawska A., Czubińska M., Górska M., Wolska K. (1964): Obserwacje fenologiczne nad drzewami i krzewami aklimatyzowanymi w Ogrodzie Botanicznym Uniwersytetu im. Adama Mickiewicza w Poznaniu w latach 1957-1961. PWN, Poznań.

BojarczuK T. (1971): Żywiciele jemioły pospolitej (Viscum album L.) w Polsce. Rocznik Sekcji Dendrologicznej Polskiego Towarzystwa Botanicznego 25: 189-203.

Bugata W. (red.) (1999): Nasze drzewa leśne. Monografie popularnonaukowe 16. Klony. Bogucki Wydawnictwo Naukowe, Poznań - Kórnik.

BugaŁa W. (2000): Drzewa i krzewy. PWRiL, Warszawa.

Chylarecki H., Straus H. (1968): Wyniki dziesięcioletnich obserwacji fenologicznych nad drzewami i krzewami w Arboretum Kórnickim. Arboretum Kórnickie 13: 37-120.

Dreiss L., Volin J. (2014): Forests: Temperate Evergreen and Deciduous. W: Y. Wang (red.). Encyclopedia of Natural Resources. Vol. 1. Land. CRC Press, Boca Raton: 214-223.

FilipczaK J. (red.) (2011): Katalog roślin: drzewa, krzewy, byliny polecane przez Związek Szkółkarzy Polskich. Agencja Promocji Zieleni, Warszawa.

FraziK-ADAmczyк M. (2004): Drzewa małych przestrzeni. Cz. 2. Odmiany o kolorowych kolumnach. Szkółkarstwo 3: 12-18.

FRÉDÉRIC L. (2005): Japan Encyclopedia. Belknap Press of Harvard University Press, Cambridge.

Gelderen D.M., Jong P.C., Oterdoom H.J. (1995): Maples of the world. Timber Press, Portland, Oregon.

GóRKA W. (2003): Sprzedać kolor. Szkółkarstwo 5: $14-17$.

GórKA W. (2005): Efektowne nie tylko latem. Szkółkarstwo 6: 12-15.
Harmata W. (1995): Fenologia ogólna. Uniwersytet Jagielloński, Kraków.

Heinze W., Schreiber D. (1987): Eine neue Kartierung der Winterhärtezonen für Gehölze in Europa. Mitteilungen der Deutschen Dendrologischen Gesellschaft 75: 11-56.

KROTOSKA T. (1958): Pory roku w życiu roślin: obserwacje fenologiczne w zespołach roślinnych. PWN, Poznań.

Lenard E., Wolski K. (2006): Dobór drzew i krzewów w kształtowaniu terenów zieleni. Wydawnictwo Akademii Rolniczej we Wrocławiu, Wrocław.

LipIŃski M. (2010): Pożytki pszczele. Zapylanie i miododajność roślin. PWRiL, Wydawnictwo Sądecki Bartnik, Warszawa.

Lis J., Pasieczna A. (2005): Badania geochemiczne w Poznaniu i okolicach. Przegląd Geologiczny 53, 6: 470-474.

ŁUKASIEWICZ A. (1984): Potrzeba ujednolicenia metodyki fenologicznej w polskich ogrodach botanicznych i arboretach. Wiadomości Botaniczne 28, 2: 153-158.

ŁUKASIEWICZ A. (1993): Rozwój klonów (Acer spp.) w kolekcjach Ogrodu Botanicznego UAM w Poznaniu, ich odporność na mrozy i susze oraz ocena przydatności poszczególnych gatunków dla terenów zieleni. Biuletyn Ogrodów Botanicznych, Muzeów i Zbiorów 2: 37-67.

ŁUKASIEWICZ A. (1995): Dobór drzew i krzewów dla zieleni miejskiej środkowo-zachodniej Polski. Wydawnictwo Naukowe UAM, Poznań.

ŁuKASIEWICZ A., GóRsKa-ZajĄCZKowsKa M. (1983): Fenologiczne pory roku w Poznaniu w latach 1968-1979. Wiadomości Botaniczne 27, 1: 67-75.

Seneta W., Dolatowski J. (2012): Dendrologia. Wydawnictwo Naukowe PWN, Warszawa.

SHENNIKOv A.P. (1928): Fenologicheskiye spektry rastitel'nykh soobshchestv. Sb. «Trudy Vologodskoy sel'skokhozyaystvennoy opytnoy stantsii», vyp. 2, Vologda: 5-21.

STYPIŃSKI P. (1997): Biologia i ekologia jemioły pospolitej (Viscum album, Viscaceae) w Polsce. PAN, Kraków.

TumiŁowicz J. (2000): Strefy klimatyczne dla uprawy drzew i krzewów w Polsce. Szkółkarstwo 4: $10-13$.

TumiŁowicz J. (2002): Klony dla terenów zieleni. Szkółkarstwo 5: 7-11.

TumiŁowicz J., Szymczak R. (1997): Klony obcego pochodzenia w uprawie drzewostanowej w Arboretum SGGW w Rogowie. Rocznik Dendrologiczny 45: 35-44.

For citation: Sowelo M., AntKowiak W. (2018): Ocena wartości ozdobnej wybranych gatunków klonów Acer L. na podstawie obserwacji fenologicznych. Steciana 22, 3: 69-83. doi: 10.12657/ steciana.022.009 